\title{
KARAKTERISTIK INDUSTRI BATU BATA DAN KONTRIBUSINYA TERHADAP KONDISI SOSIAL EKONOMI PENGRAJIN DI KECAMATAN KALIPURO, KAB. BANYUWANGI, JAWA TIMUR
}

\author{
Oleh \\ Haerfina Prambayoun Habibika \\ NIM 1114031048 \\ Jurusan Pendidikan Geografi Universitas Pendidikan Ganesha Jalan Udayana \\ Singaraja-Bali TIp. (0362) 32559 \\ e-mail: haerfina@gmail.com,wayan_ash@yahoo.com
}

\begin{abstract}
ABSTRAK
Penelitian ini dilaksanakan di Kecamatan Kalipuro, Kabupaten Banyuwangi, Provinsi Jawa Timur. Tujuan penelitian yaitu 1) Karakteristik industri batu bata di Kecamatan Kalipuro ; 2) Kontribusi industri batu bata terhadap kehidupan sosial ekonomi pengrajin di Kecamatan Kalipuro. Penelitian ini merupakan penelitian Deskriptif. Populasi penelitian ini sebanyak 284 dengan jumlah sampel sebanyak 25\% atau 71 responden. Sampel ditentukan dengan teknik Proposional Random Sampling yang dilakukan pada seluruh desa di Kecamatan Kalipuro. Metode pengumpulan data yang digunakan adalah metode observasi dan kuisioner untuk data primer serta metode pencatatan dokumen untuk data sekunder. Analisis data penelitian ini menggunakan pendekatan keruangan terkait karakteristik spasial objek penelitian. Hasil dari penelitian menunjukkan bahwa : 1) Karakteristik industri batu bata di Kecamatan Kalipuro meliputi : modal yang digunakan berhubungan dengan status pekerjaan yakni semakin tinggi status pekerjaan maka modal yang digunakan semakin besar, bahan baku yang menjadi ciri khas industri batu bata adalah sabut kelapa giling, tenaga pengrajin mayoritas bekerja dengan sistem borongan, proses pengolahan menggunakan teknologi sederhana, dan jangkauan pemasaran hingga luar kabupaten. 2)industri batu bata memberikan kontribusi sosial membantu kehidupan sosial ekonomi pengrajin batu bata yaitu membuka peluang pekerjaan dan kemampuan memenuhi pendidikan bagi anggota keluarga yang ditanggung. Sedangkan kontribusi ekonomi berupa tambahan pendapatan untuk kehidupan sehari-hari dengan rata-rata pendapatan > Rp. 1.500 .000 - Rp. 2.500 .000 per bulan. Kata Kunci : Karakteristik Industri, Pengrajin, Kontribusi Sosial Ekonomi
\end{abstract}

\begin{abstract}
This research was conducted in Kalipuro District, Banyuwangi Regency, East Java Province. The purposes of the research are 1) Characteristic of brick industry in Kalipuro District; 2) Contribution of brick industry to socio-economic life of artisans in Kalipuro District. This study categorized as descriptive research. The number of research population are 284 with the whole of samples as much as $25 \%$ or 71 respondents. The sample is determined by the technique of Propositional Random Sampling conducted on all villages in Kalipuro District. Data collection methods used are the method of observation and questionnaire for primary data and document recording method for secondary data. Analysis of this research data using Spatial approach related spatial characteristics of research objects. The result of the research shows that: 1) The characteristic of brick industry in Kalipuro District covers: the capital used relates to employment status specifically the higher the job status the more capital used, the raw material which is characteristic of the brick industry is coconut coir, majority craftsmen work with contract systems, the processing using simple technology, and outreach to outside the district. 2) The brick industry contributes socially to the socio-economic life of the brick-making craftsmen, which opens job opportunities and the ability to meet the education of the borne family members. While the economic contribution in the form of additional income for daily life with average income> Rp. 1,500,000 - Rp. 2,500,000 per month.
\end{abstract}

Keywords: Industrial Characteristics, Craftsmen, Social Economic Contributions 


\section{PENDAHULUAN}

Industri kecil dan industri rumah tangga adalah suatu bentuk perekonomian rakyat di Indonesia, apabila dikembangkan akan mampu memecahkan masalah-masalah dasar pembangunan di Indonesia. Industri ini juga mampu untuk membantu tercapainya pertumbuhan ekonomi nasional. Industri kecil berperan dalam menciptakan suatu proses industrialisasi di Indonesia yangberkesinambungan. Industrialisa si yang berkesinambungan adalah suatu proses industrialisasi yang tidak menciptakan ketergantungan industri-industri yang tercipta oleh proses itu terhadap pasar luar negeri (Tjitrosoepomo dkk, 1991). Industri kecil lebih tepat dikembangkan di daerah pedesaan karena dianggap lebih banyak menyerap tenaga kerja yang bertujuan untuk pemerataan pembangunan perekonomian. Jenisjenis industri yang dapat digarap di daerah perdesaan meliputi industri makanan dan minuman, industri tekstil, pakaian jadi dan kulit, industri kayu dan barang non kayu, industri mineral bukan logam (kecuali minyak bumi dan batu bara) dan industri logam (Prayitno dan Arsyad, 1987).

Di Kecamatan Kalipuro dalam satu titik industri, proses penggalian, pencetakan,penjemuran,pembakara $\mathrm{n}$ dan distribusi dilakukan dalam satu lokasi lahan. Keseluruhan proses tersebut dikerjakan oleh para pengrajin secara swadaya dan menggunakan teknologi yang masih sederhana. Pengusaha batu bata di Kecamatan Kalipuro biasanya mendapatkan bahan baku tanah dari menggali tanah bekas pertanian tegalan atau tanah sawah. Dalam waktu beberapa tahun Industri ini mampu menyerap tenaga kerja yang berasal dari dalam maupun di luar Kecamatan Kalipuro. Semakin maraknya pembangunan, kebutuhan akan bahan bangunan batu bata juga semakin meningkat. Pada tahun 2011 hanya terdapat 59 industri batu bata. Kemudian meningkat jumlahnya menjadi 126 pada tahun 2015 dan 130 industri pada tahun 2016. Semakin berkembangnya industri batu bata di Kecamatan Kalipuro dapat dilihat dari data kegiatan mata pencaharian Industri Batu Bata Kecamatan Kalipuro yang dikategorikan menjadi kegiatan penambangan non logam. Kegiatan yang awalnya hanya terdapat $9 \%$ dari seluruh total mata pencaharian penduduk tahun 2013 kemudian pada tahun 2015 meningkat menjadi 13\% (BPS Kecamatan Kalipuro, 2016). Dari data tersebut dapat disimpulkan bahwa kegiatan industri Batu bata di Desa Kalipuro mengalami peningkatan dalam hal kuantitas yang selanjutnya pasti akan diikuti juga peningkatan dalam hal kebutuhan akan tenaga kerja, bahan baku dan lahan yang digunakan.

Dengan terbukanya industri di Kecamatan Kalipuro memberikan peluang kepada masyarakat untuk bekerja diluar sektor pertanian. Saat observasi awal beberapa tenaga kerja pengrajin batu bata di Kecamatan Kalipuro memiliki pekerjaan utama sebagai petani. Mereka mencari sambilan pekerjaan sebagai pengrajin batu bata saat menunggu waktu panen. Dalam mendukung dan menambah pendapatan rumah tangga, tidak menutup kemungkinan untuk mencari pendapatan dari sektor lain. Peran pendapatan suami atau istri dan anggota rumah tangga lainnya sangat berpengaruh dalam menambah pendapatan rumah tangga.

Sistem Industri Batu Bata yang padat karya yaitu lebih memanfaatkan tenaga manusia dibandingkan tenaga mesin dapat menyerap tenaga kerja produktif untuk wilayah di sekitarnya. Selain itu pekerjaan pengrajin batu bata tidak memerlukan keahlian khusus 
sehingga siapapun bisa menjadi tenaga kerja. Kedatangan tenaga kerja dari desa lain juga dapat dimanfaatkan oleh masyarakat asli sekitar industri batu bata dengan usaha berdagang misalnya warung kecil yang menyediakan kebutuhan sehari-hari yang mudah untuk di jangkau. Salah satu dampak pembangunan pada aspek sosial ekonomi adalah terjadi peningkatan pendapatan rumah tangga masyarakatnya. Industri rumah tangga di perdesaan yang memberikan andil dalam menciptakan lapangan pekerjaan dan peningkatan pendapatan rumah tangga. Usaha Pembuatan bata merah di Kecamatan Kalipuro diharapkan dapatmeningkatkan pendapatannya. Dengan pendapatan yang meningkat maka kesejahteraan pengrajin bata merah diharapkan ikut meningkat. Tambahan penghasilan dari pembuatan bata merah akan berpengaruh terhadap tingkat kesejahteraan rumah tangga pengrajin industri bata merah. Usaha pembuatan bata merah di Kecamatan Kalipuro ditujukan pada upaya peningkatan pendapatan dan peningkatan taraf hidup rumah tangga. Dengan meningkatnya pendapatan diharapkan dapat kesejahteraan pengrajin bata merah meningkat.

Keberadaan Industri Batu Bata selain dapat menunjang perekonomian dan pendapatan asli daerah Kecamatan Kalipuro serta merupakan sumber mata pencaharian sebagian penduduk karena memberikan pendapatan tambahan bagi rumah tangga berpendapatan rendah di daerah pedesaan. Oleh karena itu, keberadaan atau pertumbuhan Industri Batu Bata tersebut perlu untuk dikaji dan dideskripsikan

\section{METODE}

Dalam penelitian ini, rancangan penelitian yang digunakan adalah rancangan penelitian deskriptif, untuk mendeskripsikan permasalahan yang ada dalam suatu penelitian. Berdasarkan observasi yang dilakukan peneliti dan data para pengrajin industri Kecamatan Kalipuro adalah sebanyak 284 jiwa. Pengambilan sampel menggunakan Proposional Random Sampling. Jumlah sampel diperhitungkan secara proporsional dimasingmasing desa dengan mengambil $25 \%$ dari populasi.

Teknik pengumpulan data dalam menyusun penelitian ini diperoleh melalui data sekunder dan data primer. Dataprimer diperoleh melalui observasi wilayah dan diisi wawancara. Data sekunder diperoleh dari buku-buku, arisi/dokumen, dan sumber lain. Dilihat dari permasalahan yang ada Teknik analisis data yang digunakan pada ketiga rumusan masalah tersebut adalah metode deskriptif dengan menggunakan analisis kualitatif.

HASIL

Berdasarkan observasi, wawancara dan dokumentasi yang telah dilakukan penulis maka hasil analisis data dipaparkan dalam uraian berikut.

\subsubsection{Karakteristik Industri Batu Bata Di Kecamatan Kalipuro \\ Serangkaian karakteristik} atau faktor geografis industri batu bata di Kecamatan Kalipuro meliputi modal, bahan baku tenaga kerja, proses produksi dan pemasaran. Modal merupakan salah satu faktor produksi yang utama demi kelancaran industri yang diusahakan. Sumber atau asal modal yang dikeluarkan oleh pengusaha industri batu bata 
berbeda-beda sesuai dengan status pekerjaan. Modal investasi awal merupakan modal jangka panjang yaitu alat dan bahan untuk proses produksi. Modal investasi awal yang dikeluarkan oleh pengusaha pemilik lahan lebih banyak daripada pengontrak dan pengrajin tetap. Pengusaha mengeluarkan modal awal untuk investasi lebih banyak dikarenakan menanggung lebih banyak biaya operasional.

Selain modal, bahan baku juga merupakan unsur yang penting dalam perindustrian, tanpa bahan baku suatu industri tidak akan menghasilkan produk. Jenis bahan baku utama yang digunakan dalam industri batu bata adalah tanah liat. Jadi saat pengusaha dan pengontrak lahan membeli sebidang tanah sama dengan membeli bahan baku. Bahan pendukung lainnya adalah sekam/sabut arang yang sudah dihaluskan sebagai bahan penguat, semen, air, plastik penjemur dan kayu bakar sebagai bahan bakar. Bahan baku berupa tanah liat didapat satu tempat dengan lokasi proses industri. Sedangkan bahan lainnya dipasok dari Kecamatan Kalipuro seperti kayu bakar, sekam padi, dan sabut kelapa yang didapat dari kelurahan Kalipuro dan sekitarnya. Kemudahan memperoleh bahan baku memberi keuntungan tersendiri bagi pengusaha karena menghemat biaya transportasi. Semua industri di Kecamatan Kalipuro menggunakan teknik dan proses yang sama yakni menggunakan tenaga manusia dan dengan teknologi sederhana. Proses pembuatan kegiatan produksi adalah proses penggalian, proses perendaman, proses penghalusan, proses pencampuran bahan penguat proses pencetakan dan penjemuran, proses pembakaran, dan tahap akhir yaitu menyeleksi kualitas bata sebagai proses quality control. Kegiatan proses produksi dilakukan oleh tenaga kerja dan pengusaha itu sendiri. Jumlah tenaga kerja dalam satu industri sedikitnya 1-7 tenaga kerja tergantung luas lahan garapan dan pemesanan yang harus dikerjakan. Sistem kerja sistem kerja harian ada 18 responden (25,4\%). Kemudian tenaga kerja yang menggunakan sistem borongan ada 37 responden atau $52,1 \%$ pengusaha. Sedangkan tenaga kerja yang menggunakan sistem bulanan hanya terdapat 16 responden atau $22,5 \%$. Pengusaha yang menggunakan sistem harian, upah yang diberikan sebesar Rp 50.000-Rp 70.000. Apabila dengan sistem borongan upah yang diberikan tergantung pemilik usaha. Kisaran upah berlaku di Kecamatan Kalipuro rata-rata Rp.150.000 untuk tenaga kerja yang mencetak 1000 bata mentah. Untuk upah tenaga kerja yang memproses hingga menjadi bata merah yang siap jual yaitu Rp.200.000/ 1000 buah bata merah. Kemudian untuk pengusaha yang menggunakan sistem bulanan upah dengan kisaran yang didapat sebesar Rp.1.050.000-Rp 1.300.000 yang diberikan tiap akhir bulan.

Cara pemasaran hasil produksi industri batu bata di Kecamatan Kalipuro berbeda-beda. 48 responden $(67,7 \%)$. Sedangkan sisanya adalah menggunakan cara mendistribusikan ke pedagang ecer atau agen sebanyak 23 responden $(32,3 \%)$. Berdasarkan alat angkut yang digunakan sebanyak 23 responden (32,3\%) menggunakan alat angkut truk dalam industri mereka. industri menggunakan pickup/colt. Dan sisanya mayoritas industri menggunakan pick up yaitu sebanyak 48 responden (67,7\%). Berdasarkan jangkauan pemasaran industri batu bata di Kecamatan Kalipuro juga menjangkau sampai luar Kabupaten Banyuwangi yaitu 10 responden $(14,1 \%)$ yakni hingga ke Kabupaten Situbondo yang terhitung sekitar $15-20 \mathrm{Km}$ dari pusat industri. Sisanya sebanyak 48 responden 
$(67,6 \%)$ melayani pasar dalam kota kabupaten Banyuwangi yang berdekatan dengan Kecamatan Kalipuro. Dan sebanyak 13 responden (18.3\%) melayani pasar dalam kecamatan dengan skala kecil.

\subsubsection{Kontribusi Industri Batu Bata Terhadap Status Pekerjaan \\ Pengrajin tetap yaitu 30} responden (42,3\%), pengrajin bebas/musiman sebanyak 17 responden (23,9\%), penyewa lahan yang juga ikut bekerja terhitung 16 responden $(22,5 \%)$, pemilik lahan yang juga ikut bekerja dibantu pengrajin sebanyak 6 responden $(8,5 \%)$ dan pemilik lahan yang bekerja sendiri tanpa pengrajin sebanyak 2 responden (2,8\%). Berdasarkan penghitungan skor akhir kontribusi adalah senilai 280 yang berarti kontribusi industri batu bata tinggi dalam menyerap tenaga kerja dan membantu perekonomian dari masyarakat sekitar Kecamatan Kalipuro.

Tabel 4.24 Status Pekerjaan Responden Pengrajin Industri Batu Bata

\begin{tabular}{clccc}
\hline No & \multicolumn{1}{c}{ Status Pekerjaan Responden } & Skor & Responden & \% \\
\hline 1 & Lahan Sendiri, berusaha sendiri & 1 & 2 & 2.8 \\
2 & $\begin{array}{l}\text { Lahan Sendiri, berusaha sendiri dibantu } \\
\text { pengrajin }\end{array}$ & 2 & 6 & 8.5 \\
& $\begin{array}{r}\text { Penyewa Lahan, berusaha dibantu } \\
3\end{array}$ & 3 & 16 & 22.5 \\
& $\begin{array}{l}\text { pengrajin } \\
4\end{array}$ & 4 & 17 & 23.9 \\
5 & Pengrajin bebas/musiman & 5 & 30 & 42.3 \\
$\quad$ Pengrajn Tetap & & $\mathbf{7 1}$ & $\mathbf{1 0 0}$ \\
\hline
\end{tabular}

Skor Akhir = 280 (tinggi)

\subsubsection{Kontribusi Industri Batu Bata Terhadap Pendidikan Hasil Penelitian menunjukkan} bahwa tenaga kerja industri batu bata yang tidak tamat SD/ tidak bersekolah adalah 11 pengrajin (15,5\%), yang tamat SD adalah 24 pengrajin $(33,8 \%)$, yang tamat SMP adalah 30 pengrajin $(42,3 \%)$ dan yang tamat SMA adalah 6 pengrajin (8,5\%). Dengan hasil akhir skor sebesar 173 yang berarti Industri

\section{Tabel 4.25 Pendidikan Terakhir}

batu bata di Kecamatan Kalipuro mayoritas mempekerjaan tenaga kerja dengn pendidikan sedang karena untuk menjadi pengrajin batu bara dengan cara tradisional tidak menuntut memiliki pendidikan tinggi sehingga tenaga kerja dengan pendidikan rendah pun bisa bekerja di industri batu bata asalkan memiliki keterampilan dalam memproduksi batu bata.

\section{7}

\begin{tabular}{clccc}
\hline No & Pendidikan Terakhir Pengrajin & Skor & Jumlah & \% \\
\hline 1 & Tidak Tamat SD/Tidak Sekolah & 1 & 11 & 15.5 \\
2 & SD & 2 & 24 & 33.8 \\
3 & SMP & 3 & 30 & 42.3 \\
4 & SMA & 4 & 6 & 8.5 \\
5 & PT & 5 & - & -
\end{tabular}

Jumlah

71

100

Skor Akhir = 173 (sedang)

Sumber : Hasil Penelitian, 2017 
Pengrajin mempu memenuhi pendidikan anggota keluarga yang ditanggung terbanyak adalah jenjang SMP sebanyak 24 pengrajin (57\%). Jenjang SD 9 pengrajin $(21,4 \%)$, SMA sebanyak 7 pengrajin $(16,7 \%)$ dan PT sebanyak 2 pengrajin $(4,8 \%)$. Dapat disimpulkan bahwa dengan pendapatan yang didapat dari industri batu bata, pengrajin di Kecamatan Kalipuro masih mampu memberikan kebutuhan pendidikan

Tabel 4.27 Pendidikan Anak Yang Ditanggung Pengrajin Industri Batu Bata Kec. Kalipuro 2017

\begin{tabular}{|c|c|c|c|}
\hline No & $\begin{array}{c}\text { Pendidikan Anak Yang } \\
\text { Ditanggung }\end{array}$ & Jumlah & $\%$ \\
\hline 1 & Tidak Tamat SD/Tidak Sekolah & - & 0 \\
\hline 2 & $\mathrm{SD}$ & 9 & 21.4 \\
\hline 3 & SMP & 24 & 57.1 \\
\hline 4 & SMA & 7 & 16.7 \\
\hline 5 & PT & 2 & 4.8 \\
\hline & Jumlah & 42 & 100 \\
\hline
\end{tabular}

Sumber : Hasil Penelitian, 2017

\subsubsection{Kontribusi Industri Batu Bata Terhadap Pendapatan \\ Pendapatan atau upah dari} tenaga kerja industri batu bata yang diperoleh sangat bervariasi. Pengrajin yang mendapat upah > Rp. 1.500 .000 - Rp. 2.500 .000 yaitu 30 pengrajin $(42,3 \%)$, besaran upah $>$ Rp. >Rp. 500.000 - Rp. 1.500 .000 dimiliki 25 pengrajin $(35,2 \%),<R p$. 500.000 dimiliki 2 pengrajin $(2,8 \%)$, > Rp. 2.500 .000 - Rp. 3.500 .000 dimiliki oleh 13 pengrajin (1.8\%), yakni > Rp. 3.500.000 dimiliki hanya 1 pengrajin $(1,4 \%)$. Skor penghitungan yang didapat yaitu sebesar 212 yang berarti kontribusi industri batu bata terhadap pendapatan pengrajinnya dalam kategori sedang. Hal ini sudah dianggap mampu memberikan kontribusi terhadap pendapatan masyarakat pengrajin di Kecamatan Kalipuro.

Tabel 4.28 Pendapatan Pengrajin Industri Batu Bata di Kecamatan Kalipuro 2017

\begin{tabular}{clccc}
\hline No & \multicolumn{1}{c}{ Pendapatan Responden/Bulan } & Skor & Responden & \% \\
\hline 1 & < Rp. 500.000 & 1 & 2 & 2.8 \\
2 & >Rp. 500.000 - Rp. 1.500 .000 & 2 & 25 & 35.2 \\
3 & > Rp. $1.500 .000-$ Rp. 2.500 .000 & 3 & 30 & 42.3 \\
4 & > Rp. 2.500.000 - Rp. 3.500.000 & 4 & 13 & 18.3 \\
5 & > Rp. 3.500.000 Jumlah & 5 & 1 & 1.4 \\
& & & $\mathbf{7 1}$ & $\mathbf{1 0 0}$ \\
\hline
\end{tabular}

Skor Akhir = 212

Sumber : Hasil Penelitian, 2017

\section{PEMBAHASAN}

\subsubsection{Karakteristik Industri Batu Bata Di Kecamatan Kalipuro Serangkaian karakteristik} atau faktor geografis industri batu bata di Kecamatan Kalipuro meliputi modal, bahan baku tenaga kerja, proses produksi dan pemasaran. Modal merupakan salah satu faktor produksi yang utama demi kelancaran industri yang diusahakan. Sumber atau asal 
modal yang dikeluarkan oleh pengusaha industri batu bata berbeda-beda sesuai dengan status pekerjaan. Modal investasi awal merupakan modal jangka panjang yaitu alat dan bahan untuk proses produksi. Modal investasi awal yang dikeluarkan oleh pengusaha pemilik lahan lebih banyak daripada pengontrak dan pengrajin tetap. Pengusaha mengeluarkan modal awal untuk investasi lebih banyak dikarenakan menanggung lebih banyak biaya operasional. Secara teoritis memang dalam masyarakat terdapat kelas-kelas sosial dimana suatu kelas pemegang modal yang mengatur kelas lain yang dominan. Pada akhirnya hubungan ekonomi inilah yang mengatur hubungan sosial kemasyarakatan.

Selain modal, bahan baku juga merupakan unsur yang penting dalam perindustrian, tanpa bahan baku suatu industri tidak akan menghasilkan produk. Jenis bahan baku utama yang digunakan dalam industri batu bata adalah tanah liat. Jadi saat pengusaha dan pengontrak lahan membeli sebidang tanah sama dengan membeli bahan baku. Bahan pendukung lainnya adalah sekam/sabut arang yang sudah dihaluskan sebagai bahan penguat, semen, air, plastik penjemur dan kayu bakar sebagai bahan bakar. Bahan baku berupa tanah liat didapat satu tempat dengan lokasi proses industri. Sedangkan bahan lainnya dipasok dari Kecamatan Kalipuro seperti kayu bakar, sekam padi, dan sabut kelapa yang didapat dari kelurahan Kalipuro dan sekitarnya. Kemudahan memperoleh bahan baku seperti sabut kelapa giling memberi keuntungan tersendiri bagi pengusaha karena menghemat biaya transportasi. Semua industri di Kecamatan Kalipuro menggunakan teknik dan proses yang sama yakni menggunakan tenaga manusia dan dengan teknologi sederhana. Proses pembuatan kegiatan produksi adalah proses penggalian, proses perendaman, proses penghalusan, proses pencampuran bahan penguat proses pencetakan dan penjemuran, proses pembakaran, dan tahap akhir yaitu menyeleksi kualitas bata sebagai proses quality control. Jarak spasial antara industri dengan lokasi mendapatkan bahan baku yang berdekatan memudahkan pemilik industri dalam memenuhi kebutuhan produksi. Terdapat persamaan kebutuhan bahan baku dan bahan pendukung antara industri satu dengan yang lain menyebabkan adanya karakteristik industri tersendiri di Kecamatan Kalipuro.

Kegiatan proses produksi industri batu bata Kecamatan Kalipuro dilakukan oleh tenaga kerja dan pengusaha itu sendiri. Jumlah tenaga kerja dalam satu industri sedikitnya 1-7 tenaga kerja tergantung luas lahan garapan dan pemesanan yang harus dikerjakan. Jika lahan garapan yan dikerjakan luas maka tenaga yang dibutuhkan akan lebih banyak. Kelurahan Kalipuro dan Desa Klatak menjadi pemasok tenaga kerja terbanyak karena bisa jadi disebabkan oleh demografi Kecamatan Kalipuro dimana penduduk paling banyak terdapat pada wilayah tersebut. Sebab lain adalah luasnya pertanian pada Kelurahan Kalipuro dan Klatak sehingga mayoritas dari tenaga kerja musiman berasal dari masyarakat petani yang mengisi waktu luang menunggu panen.

Sistem kerja yang digunakan tenaga kerja Industri di Kecamatan Kalipuro menggunakan sistem harian, borogan, dan bulana. Pengrajin paling banyak bekerja dengan sistem borongan karena dianggap lebih menguntungkan. Tidak setiap hari atau setiap bulan ada pemesanan batu bata jadi sehingga apabila menggunakan sistem borongan, baik ada pesanan 
atau tidak pengrajin akan mendapat upah sesuai jumlah bata yang dibuat. Apabila dengan sistem borongan upah yang diberikan ratarata Rp.150.000 untuk tenaga kerja yang mencetak 1000 bata mentah. Untuk upah tenaga kerja yang memproses hingga menjadi bata merah yang siap jual yaitu Rp.200.000/ 1000 buah bata merah

$$
\text { Cara pemasaran hasil }
$$
produksi industri batu bata di Kecamatan Kalipuro berbeda-beda. Mayoritas industri memiliki langganan sendiri sehingga pembeli datang ke lokasi industri secara langsung. Berdasarkan alat angkut industri batu bata Kecamatan Kalipuro banyak memakai pickup atau colt yang berhubungan dengan jumlah bata yang dipesan dan lokasi pemesanan. Berdasarkan jangkauan pemasaran terjauh industri batu bata di Kecamatan Kalipuro menjangkau sampai luar Kabupaten Banyuwangi. Mayoritas industri batu bata melayani permintaan pasar dalam kota kabupaten Banyuwangi dan sisanya hanya melayani pasar dalam Kecamatan dengan skala kecil.

\subsubsection{Kontribusi Industri Batu Bata Terhadap Status Pekerjaan}

Berdasarkan hasil penelitian masyarakat pengrajin yang terdata mayoritas menempati status sebagai pengrajin tetap dengan kontribusi terhadap penyerapan tenaga kerja yang tinggi. Dengan mengetahui status pekerjaan maka akan diketahui jumlah tenaga kerja, pemilik dan pengontrak sehingga dapat diketahui hak dan kewajiban yang harus dipenuhi sesuai tingkatan pekerjaan. Industri kecil seperti industri batu bata lebih tepat dikembangkan di daerah pedesaan karena dianggap lebih banyak menyerap tenaga kerja. Sifat industri batu bata yang lokakarya atau lebih mengedepankan tenaga manusia sangat berguna menyerap tenaga kerja produktif yang paling banyak terdapat di Kecamatan Kalipuro. Dengan demikian, dari semua indikator status pekerjaan di industri batu bata Kecamatan Kalipuro dianggap berkontribusi untuk masyarakat sekitarnya dalam menyediakan lapangan pekerjaan.

\subsubsection{Kontribusi Industri Batu Bata Terhadap Pendidikan}

Hasil Penelitian menunjukkan

bahwa tenaga kerja industri batu bata paling banyak pernah mengenyam pendidikan hingga tamat SMP yang berarti industri batu bata di Kecamatan Kalipuro mayoritas mempekerjaan tenaga kerja dengn pendidikan sedang karena untuk menjadi pengrajin batu bara dengan cara tradisional tidak menuntut memiliki pendidikan tinggi sehingga tenaga kerja dengan pendidikan rendah pun bisa bekerja di industri batu bata asalkan memiliki keterampilan dalam memproduksi batu bata. Pendidikan dan kualitas tenaga kerja sangat berpengaruh terhadap proses produksi. Semakin tinggi tingkat pendidikan tenaga kerja maka akan semakin berkualitas dan terampil dalam melakukan pekerjaan. Namun dalam hasil penelitian menunjukkan bahwa industri batu bata berkontribusi sangat baik bahkan untuk menyerap tenaga kerja yang memiliki pendidikan rendah sekalipun. Hal tersebut sangat berguna untuk mengurangi angka pengangguran dan beban ketergantungan.

Pendapatan rumah tangga yang tinggi salah satunya dapat berdampak pada kemampuan suatu keluarga tidak hanya memenuhi kebutuhan sandang, pangan dan papan saja namun juga kebutuhan untuk pendidikan anggota keluarganya sehingga terjadi perbaikan taraf hidup. Pengrajin mampu memenuhi pendidikan anggota keluarga yang ditanggung 
terbanyak adalah jenjang SMP sebanyak 24 pengrajin (57\%). Jenjang SD 9 pengrajin $(21,4 \%)$, SMA sebanyak 7 pengrajin $(16,7 \%)$ dan PT sebanyak 2 pengrajin $(4,8 \%)$. Dapat disimpulkan bahwa dengan pendapatan yang didapat dari industri batu bata, pengrajin di Kecamatan Kalipuro masih mampu memberikan kebutuhan pendidikan bagi anggota keluarga yang ditanggung.

1.2.8 Kontribusi Industri Batu Bata Terhadap Pendapatan Kegiatan kewirausahaan yang merupakan salah satu industri yang mampu menyerap tenaga kerja yang banyak tentunya berperan penting bagi kesejahteraan hidup masyarakat. Secara umum adanya industri batu bata di Kecamatan Kalipuro mendukung untuk meningkatkan kesejahteraan pengrajinnya. Industri rumah tangga di perdesaan yang memberikan andil dalam menciptakan lapangan pekerjaan dan peningkatan pendapatan rumah tangga.

Pendapatan atau upah dari tenaga kerja industri batu bata yang diperoleh sangat bervariasi.

\section{SARAN}

Berdasarkan pada hasil penelitian, pembahasan dan simpulan, maka dapat diajukan saran sebagai berikut

1. Bagi Pemerintah, Hasil penelitian ini dapat dijadikan sebagai bahan masukan dalam perencanaan pembangunan wilayah sehingga Kecamatan Kalipuro dalam melaksanakan kegiatan industri yang terencana dan dapat membangun perekonomian pedesaan.
Mayoritas pengrajin yang mendapat upah pendapatan > Rp. 1.500.000 Rp. 2.500.000. Tinggi rendahnya pendapatan tergantung pada intensitas pembuatan batu bata. Banyaknya pengrajin yang menggunakan sistem kerja borongan akan member kesempatan lebih banyak dalam menerima upah karena semakin banyak bata yang dibuat akan semakin banyak upah yang didapatkan. Hal tersebut sangat menguntungkan bagi pengrajin tetap maupun tidak tetap. Dengan pendapatan yang meningkat maka kesejahteraan pengrajin bata merah diharapkan ikut meningkat. Tambahan penghasilan dari pembuatan bata merah akan berpengaruh terhadap tingkat kesejahteraan rumah tangga pengrajin industri bata merah. Berdasarkan hasil penelitian kontribusi industri batu bata terhadap pendapatan pengrajinnya dalam kategori sedang. Hal ini sudah dianggap mampu memberikan kontribusi terhadap pendapatan masyarakat pengrajin di Kecamatan Kalipuro.

2. Bagi masyarakat, penelitian ini dapat dijadikan sebagai informasi mengenai karakteristik industri batu bata dan kontribusi sosial ekonomi di Kecamatan Kalipuro.

3. Bagi Peneliti. Hasil penelitian ini hendaknya dapat dijadikan acuan bagi peneliti selanjutnya dengan subjek dan lokasi yang berbeda sehingga hasil yang diharapkan menjadi lebih sempurna. 
DAFTAR PUSTAKA

Arikunto, Suharsimi. 1986. Prosedur Penelitian Suatu Pendekatan Praktek. Jakarta : Binaaksara

Arif Sukadi Sadiman. 1990. Metode dan Analisa Penelitian. Jakarta : Erlangga

Arikunto, S., 2006. Prosedur Penelitian Suatu Pendekatan Praktik.Jakarta : Rineka Cipta

Badan Pusat Statistik. 2016. Statistik Daerah Kabupaten Banyuwangi. Banyuwangi : Biro Pusat Statistik Kabupaten Banyuwangi

Geombong Tjitrosoepomo.1991. Industri Pedesaan dan Masalah Pengembangannya : Seminar Nasional Pedesaan dalam Rangka Lustrum I Universitas Wangsa Manggala.Yohyakarta:Aditya Media

Ida Bagus Mantra.2003.Demografi Umum. Edisi ke-2. Yogyakarta : Pustaka Belajar.

Ramli. 2007. Pengaruh Pemberian Material Limbah Serat Alami terhadap Sifat Fisika Bata Merah. Skripsi FMIPA. Universitas Negeri Padang Sumatera Barat

Standar Nasional Indonesia. 2000. Bata Merah Pejal untuk Pasangan Dinding. SNI 15-2094-2000

Subri, Mulyadi.2003.Ekonomi Sumber Daya Manusia. Jakarta: PT Raja Grafindo Persada

Tulus Tambunan.2001. Usaha Kecil dan Menengah di Indonesia : Salemba Empat

Todaro, Michael P. 2000.Pembangunan Ekonomi di Dunia Ketiga. Jakarta: Erlangga

Sumaatmadja, Nursdi.1998.Manusia dalam konteks Sosial, budaya, dan lingkungan hidup. Bandung : Cv Alfabeta 